\title{
Influencia de la naturaleza del cemento en la compatibilidad con aditivos superplastificantes basados en carboxilatos
}

\section{Effect of the cement type on compatibility with carboxylate superplasticisers}

\author{
G. Bundyra-Oracz ${ }^{(*)}, \underline{\text { W. Kurdowski }}{ }^{(* *)}$
}

Recepción/Received: 1-IX-09

Aceptación/Accepted: 26-II-10

Publicado online/Online publishing: 20-VI-11

RESUMEN

En el presente trabajo se ha realizado un estudio empírico con el objetivo de profundizar en el conocimiento de las interacciones del sistema cemento-superplastificante. Con este fin, se prepararon dos clínkeres con una composición química y de fases conocida: el primero (C1) sin aluminato tricálcico y el segundo (C2) con un contenido en $C_{3} A$ del $9 \%$. Ambos se molieron hasta obtener una superficie específica aproximada de $340 \mathrm{~m}^{2} / \mathrm{kg}$ y se emplearon con dos adiciones: yeso y el compuesto de Klein $\left(3 \mathrm{CaO} \cdot 3 \mathrm{Al}_{2} \mathrm{O}_{3} \cdot \mathrm{CaSO}_{4}\right)(1,2)$. Se añadió la cantidad necesaria del compuesto de Klein a C1 para garantizar la formación, tras 0,5 y $1^{\mathrm{a}} \mathrm{h}$. de hidratación, de aproximadamente la misma cantidad de etringita en dicho cemento que en la mezcla de cemento $\mathrm{C} 2$ y yeso. Se empleó un superplastificante basado en carboxilatos. Los resultados reológicos obtenidos han demostrado que si bien el esfuerzo de cizalla umbral de las pastas muestra una buena correlación con la formación de la etringita, no existe una relación tan clara entre dicho parámetro y la viscosidad plástica. Ésta depende de la cantidad total de hidratos que se generen, es decir, no sólo en forma de etringita sino también como gel C-S-H. A partir de los resultados de los ensayos realizados, se puede afirmar que la formación de etriginta es el factor determinante en la reología de las pastas de cemento preparadas con clínkeres con bajo contenido en sulfato y potasio y aditivadas con un superplastificante basado en carboxilatos.

Palabras clave: reología, superplastificante, cemento Pórtland, sulfoaluminato de calcio, silicato de calcio hidratado.
SUMMARY

An empirical study was conducted to gain a fuller understanding of the interactions taking place in cementsuperplasticiser systems. To this end, two clinkers of known chemical and phase composition were prepared in this study to gain insight into such interactions. One contained no tricalcium aluminate (C1), while the other had a $9 \% C_{3} A$ content (C2). These clinkers were ground to approximately $340 \mathrm{~m}^{2} / \mathrm{kg}$ and blended with gypsum only or gypsum and Klein compound $\left(3 \mathrm{CaO} \cdot 3 \mathrm{Al}_{2} \mathrm{O}_{3} \cdot \mathrm{CaSO}_{4}\right)$ $(1,2)$. Sufficient compound was added to $C 1$ to ensure the formation of about the same amount of ettringite after 0.5 and $1 \mathrm{~h}$ of hydration as found in cement $\mathrm{C2}+$ gypsum. The admixture used was a carboxylate superplasticiser. Rheology measurements showed that while paste yield stress was correlated to ettringite formation, no such simple relationship was observed for plastic viscosity. Plastic viscosity depended on the total hydrates formed, i.e., not only as ettringite but also as $\mathrm{C}-\mathrm{S}-\mathrm{H}$ gel. The findings revealed that in clinkers with very low sulfate and potassium contents, the rheology of carboxylate-containing cement paste is primarily controlled by ettringite formation.

Keywords: rheology, superplasticizer, Portland cement, calcium sulfoaluminate, calcium silicate hydrate.

\footnotetext{
(*) Building Research Institute (Warsaw, Poland).

(**) Research Institute of Mineral Building Materials (Krakow, Poland).
} 


\section{INTRODUCCIÓN}

En la actualidad, el uso de superplastificantes (SP) resulta fundamental para el desarrollo de la tecnología del hormigón (1-4) siendo la compatibilidad del sistema cemento-superplastificante un factor de gran relevancia en este sentido. Se entiende por sistema compatible aquel en que el hormigón resultante tiene una baja relación agua-cemento y es capaz de mantener una viscosidad baja durante un periodo de tiempo determinado, normalmente superior a los 90 minutos (3).

Los numerosos trabajos en que se ha tratado este tema han aportado unos avances importantes en el conocimiento de los mecanismos implicados. Dichos trabajos pueden clasificarse en al menos cuatro grupos, en función de los principales aspectos analizados:

1) las propiedades del cemento, en especial la composición por fases y la superficie específica (2-7);

2) los tipos de sulfatos de calcio $(3,5,8,9)$;

3) las adsorción del superplastificante (4-7);

4) la masa molecular y la composición del superplastificante $(8,9-11)$.

Entre las propiedades del cemento estudiadas se encuentran el $C_{3} A(2,3,5,7,12)$, los sulfatos alcalinos (2-4), la superficie específica $(5,6)$ y los sulfatos de calcio $(3,5$, $8,9)$. El componente más importante del cemento es el $\mathrm{C}_{3} \mathrm{~A}$, que puede ser altamente reactivo y sobre el que se adsorbe el SP en proporciones elevadas (4). El aluminato tricálcico desempeña un papel fundamental, sobre todo en el caso de los superplastificantes que contienen grupos sulfonatos (4). Ramachandran (4) y Aïtcin (3) comprobaron que el mecanismo de la reacción del $\mathrm{C}_{3} \mathrm{~A}$ consiste en la quimisorción de aniones de $\mathrm{RSO}_{3}{ }^{-}$sobre los sitios activos de la superficie del $\mathrm{C}_{3} \mathrm{~A}$. Los aniones de $\mathrm{SO}_{3}{ }^{-}$compiten en dicha quimisorción con los iones de $\mathrm{SO}_{4}{ }^{-2}$ procedentes de la disolución de sulfatos, que pueden ser alcalinos o de calcio. Bonen y Sarkar (6) observaron también una buena correlación entre la adsorción del superplastificante y el producto resultante de multiplicar la fracción de $\mathrm{C}_{3} \mathrm{~A}$ por la superficie específica del cemento. Estos autores concluyeron que la fluidez inicial de la pasta está determinada fundamentalmente por la superficie específica y el contenido en $\mathrm{C}_{3} \mathrm{~A}$ del cemento.

En los muchos estudios en los que se describe la influencia de los sulfatos alcalinos $(7,13)$ se ha observado que la adición de $\mathrm{Na}_{2} \mathrm{SO}_{4}$ puede mejorar las propiedades reológicas de las fases del cemento $(2,13)$. Jiang y col. (2) observaron que el contenido de sulfatos alcalinos es uno de los principales parámetros que influyen en la fluidez y la pérdida de esta propiedad en las pastas de cemento que contienen superplastificantes basados en el polinaftaleno sulfonato (PNS). En lo que respecta a la fluidez,

\section{INTRODUCTION}

The use of superplasticizers (SP) is currently crucial to concrete technology (1-4). Cement-superplasticiser compatibility is of cardinal importance in this regard. A compatible system is understood to mean a system that yields a concrete with a low water/cement ratio able to maintain low viscosity for a given period of time, usually no shorter than 90 minutes (3).

Much experimental work has been done to study this problem and great progress has been made in understanding its mechanisms. The papers published on the subject can be classified into at least four categories, depending on the factors studied:

1) cement properties, primarily phase composition and fineness (2-7);

2) type of calcium sulfate $(3,5,8,9)$;

3) superplasticiser adsorption (4-7);

4) superplasticiser molecular mass and composition (8, 9-11).

The cement-related properties studied include: $C_{3} A(2$, $3,5,7,12)$, alkaline sulfates (2-4), fineness $(5,6)$, and (type of) calcium sulfates $(3,5,8,9)$. The most important component in cement is $C_{3} A$, which can be highly reactive and onto which $S P$ readily adsorbs (4). Tricalcium aluminate plays an essential role, especially with superplasticizers containing sulfonate groups (4). Ramachandran (4) and Aitcin (3) reported that the $C_{3} A$ reaction mechanism involves the chemisorption of $\mathrm{SO}_{3}$ anions on active sites on the $C_{3} A$ surface. In this reaction, the $\mathrm{RSO}_{3}^{-}$anions compete with $\mathrm{SO}_{4}^{-2}$ ions present in the alkali or the calcium sulfate solution. Bonen and Sarkar (6) also found a very high correlation between superplasticiser adsorption and the product of the proportion of $C_{3} A$ times cement fineness. These authors concluded that the initial flow of cement paste was mainly governed by the fineness of and $C_{3} A$ content in a given cement.

Many papers have been published on the effect of alkaline sulfates $(7,13)$. The addition of $\mathrm{Na}_{2} \mathrm{SO}_{4}$ has been found to improve the rheological properties of cement phases $(2,13)$. Jiang et al. (2) also reported that the alkaline sulfate content was one of the major parameters controlling flowability and the loss of that property in cement pastes containing a polynaphthalene sulfonate superplasticiser (PNS). According to these authors, the optimum soluble alkaline content in terms of 
estos autores vieron que el contenido óptimo en álcalis solubles es el $0,4-0,5 \%$ del $\mathrm{Na}_{2} \mathrm{O}_{\mathrm{e}}$. En un cemento con esta cantidad óptima de álcalis solubles, el contenido en $\mathrm{C}_{3} \mathrm{~A}$ apenas afecta a la pérdida de fluidez.

Sin embargo, la asignación al $\mathrm{C}_{3} \mathrm{~A}$ de un papel decisivo en la reología de las pastas de cemento no ha sido unánime. Ramachandran (4), por ejemplo, afirma que un superplastificante se adsorbe en los productos de hidratación pero no en las fases sin hidratar. En esa misma línea, Prince y col. (11) afirman que la etringita, así como la modificación de su formación en presencia de PNS, influye de forma decisiva en la reología de las pastas de cemento. En concreto, la adición de PNS retrasa el crecimiento de las largas agujas de etringita que suelen reducir la fluidez de la pasta. Estos autores $(8,11)$ señalan que la interacción de las moléculas de SP con los gérmenes cristalinos de etringita podría explicar también el elevado consumo de moléculas de superplastificante en las primeras fases de hidratación. Cabe destacar, sin embargo, que la mezcla estudiada en este caso (11) presentaba diferencias importantes con los sistemas cementicios reales.

Por otra parte, según Kim y col. (10) los cementos que presentan una mayor capacidad de adsorción de superplastificantes de tipo PNS son incompatibles con dichos aditivos. Según estos autores, la causa de esta mayor capacidad de adsorción sería la escasez de sulfatos alcalinos solubles en el cemento. De hecho, con la incorporación de $\mathrm{Na}_{2} \mathrm{SO}_{4}$ y la consiguiente reducción de la cantidad de PNS adsorbido, se aumenta el escurrimiento del cono. Esta observación, que apunta a que una elevada adsorción está relacionada con la incompatibilidad, contradice la opinión general de que la absorción del superplastificante afecta positivamente a la reología de las pastas del cemento al aumentar las fuerzas de repulsión electrostática entre las partículas de cemento. Los autores justifican esta discrepancia indicando que las moléculas de PNS que permanecen disueltas podrían actuar como una barrera de repulsión adicional entre las partículas del cemento, contribuyendo a un aumento aún mayor de fluidez de la pasta. Además, a medida que se produce la hidratación, las moléculas de PNS adsorbidas sobre las superficies sólidas se vuelven ineficaces porque se incorporan a los productos de hidratación que se van formando. El PNS que queda en la disolución se adsorbe progresivamente a las superficies recién hidratadas, por lo que un aporte continuado de moléculas de PNS mantendría las fuerzas electrostáticas y estéricas de repulsión conservando de esa manera la fluidez de la pasta (10).

Independientemente de estos importantes resultados experimentales, es necesario profundizar en el conocimiento de los mecanismos de actuación de los superplastificantes para establecer su compatibilidad con el flowability is $0.4-0.5 \% \quad \mathrm{Na}_{2} \mathrm{O}_{e}$. In cements with this optimum amount of soluble alkalis, the $C_{3} A$ content has practically no effect on flowability loss.

$C_{3} A$ has not been universally observed to have a decisive influence on cement paste rheology, however. Ramachandran (4), for instance, reported that superplasticisers adsorbed onto the hydration products rather than the unhydrated phases. Similarly, Prince et al. (11) maintained that ettringite and its modification in the presence of PNS was the determining factor in cement paste rheology. More specifically, they found that the growth of long ettringite needles that usually reduce paste flowability was retarded when PNS was added. This research group $(8,11)$ stressed that the interaction of SP molecules with ettringite particles might also explain the high consumption of these molecules in the early stages of hydration. The blend studied (11) was fairly different from real cement systems, however.

Kim et al. (10) found cements having a high PNS adsorption capacity to be incompatible with such superplasticizers. High adsorption capacity was the result of a dearth of soluble alkaline sulfates in the cement. Indeed, with the addition of $\mathrm{Na}_{2} \mathrm{SO}_{4}$ and the concomitant decline in the amount of PNS adsorbed, the slump area grew. The existence of such a link between high adsorption and incompatibility clashes with the generally accepted assumption that superplasticiser adsorption affects cement paste rheology positively by increasing the electrostatic forces that lead to repulsion between cement particles. The authors explained this discrepancy by indicating that the PNS molecules remaining in solution might act as an additional repulsive barrier between cement particles, thereby contributing to greater paste flowability. As hydration proceeds, the PNS molecules adsorbed on the solid surfaces become ineffective because they are taken up into newly formed hydration products. The PNS remaining in the solution is then progressively adsorbed onto the newly hydrated surfaces; a continuous supply of PNS molecules would thus maintain the electrostatic and steric repulsive forces and with them paste flowability (10).

Despite these significant experimental findings, a much better understanding of superplasticiser action mechanisms is needed to control their compatibility with cement. The question posed is which phase plays 
cemento. Más concretamente, lo que debe determinarse es cuál de los elementos influye de manera más decisiva: el aluminato no hidratado o el producto de su hidratación, la etringita.

Con el fin de obtener nuevos resultados que permitan avanzar en el conocimiento del tema, en el presente trabajo se ha adoptado un nuevo enfoque experimental. Para poder diferenciar la influencia del $\mathrm{C}_{3} \mathrm{~A}$ de la de la etringita se analizaron una serie de mezclas en las que se emplearon distintas fuentes de aniones de aluminatos, en concreto $C_{3} A$ y el compuesto de Klein $\left(C_{4} A_{3} \bar{S}\right)$. Como materiales básicos se emplearon dos clínkeres industriales: uno sin $\mathrm{C}_{3} \mathrm{~A}$ y el otro con un $9 \%$ de esta fase. Al primer clínker se le añadió el compuesto de Klien para producir etringita en ausencia de $\mathrm{C}_{3} \mathrm{~A}$.

\section{MATERIALES Y MÉTODOS}

En la Tabla 1 se presentan la densidad específica, la composición por fases y el contenido en álcalis de ambos clínkeres industriales. the decisive role: unhydrated aluminate or the product of its hydration, ettringite.

A new experimental approach was adopted in this study to obtain findings that would provide greater insight into the matter. A number of blends were examined containing aluminate anions from difference sources, namely $C_{3} A$ and Klein compound $\left(C_{4} A_{3} \bar{S}\right.$, to differentiate between the effects of $C_{3} A$ and ettringite. Two industrial clinkers were used as the basic materials: one with no $C_{3} A$ and the other containing $9 \%$ of the compound. Klein compound was added to the former to produce ettringite in the absence of $C_{3} A$.

\section{MATERIALS AND METHODS}

The phase composition, specific gravity and alkali content of the two industrial clinkers are given in Table 1.

Tabla 1 / Table 1

Composición de los clínkeres*.

Clinker composition*.

\begin{tabular}{|c|c|c|}
\hline Propiedad / Property & Clínker 1 & Clínker 2 \\
\hline Densidad específica / Specific gravity $\left(\mathrm{g} / \mathrm{cm}^{3}\right)$ & 3.27 & 3.16 \\
\hline $\mathrm{C}_{3} \mathrm{~S}(\%)$ & 58 & 62 \\
\hline $\mathrm{C}_{2} \mathrm{~S}(\%)$ & 20 & 9 \\
\hline $\mathrm{C}_{3} \mathrm{~A}(\%)$ & 0 & 9 \\
\hline $\mathrm{C}_{4} \mathrm{AF}(\%)$ & 19 & 0.32 \\
\hline Cal libre / Free lime & 0.72 & 0.09 \\
\hline $\mathrm{Na}_{2} \mathrm{O}(\%)$ & 0.12 & 0.13 \\
\hline $\mathrm{K}_{2} \mathrm{O}(\%)$ & 0.11 & 0.17 \\
\hline $\mathrm{Na}_{2} \mathrm{O}$ equiv. (\%) & 0.19 & 0.22 \\
\hline $\mathrm{SO}_{3}(\%)$ & 0.24 & 1.00 \\
\hline $\mathrm{SO}_{3} / \mathrm{Na}_{2} \mathrm{O}_{\mathrm{e}}^{* *}$ & 0.98 & \\
\hline $\mathrm{Compl}^{*}$ & & \\
\hline
\end{tabular}

Nota / Note: * Composición por fases según el cálculo de Bogue. ** Relación molar. / * Phase composition calculated by Bogue's method. ** Molar ratio.

En lo que a la composición intersticial por fases se refiere, estos dos clínkeres son muy distintos entre sí. En el primero sólo se encuentra $\mathrm{C}_{4} \mathrm{AF}$, mientras que el segundo contiene un $9 \%$ tanto de aluminato como de ferrita, una característica propia de los clínkeres polacos. El contenido en álcalis es muy bajo, más de lo habitual, debido a la extracción de los gases de escape del horno durante la calcinación. El contenido de azufre también es muy bajo, mientras que la relación molar $\mathrm{Na}_{2} \mathrm{O}_{\mathrm{e}} / \mathrm{SO}_{3}$ tiene un valor próximo a 1 . Esto significa que los álcalis están presentes en forma de sulfatos y sólo en pequeñas cantidades, representando aproximadamente un $0,5 \%$.
These two clinkers had very different interstitial phase compositions: the first contained only $C_{4} A F$, while the second contained $9 \%$ of both the aluminate and the ferrite, which is typical of Polish clinkers. The alkali content was much lower than normal, because a kiln exit gas by-pass was applied during burning. The sulfur content was also very low, while the $\mathrm{Na}_{2} \mathrm{O}_{e} / \mathrm{SO}_{3}$ molar ratio was approximately 1. In other words, the alkalis were present as sulfates and in small quantities only, around $0.5 \%$. 
Además de los dos clínkeres, se preparó el compuesto de Klein mediante la calcinación de crudo con la composición adecuada en un horno rotatorio de pequeño tamaño a $1.300{ }^{\circ} \mathrm{C}$. En el análisis de difracción por rayos $\mathrm{X}$ (DRX) de este producto no se detectó ningún otro componente, aunque por medios químicos se determinó un contenido en cal libre del 0,3\%.

El yeso añadido a ambos cementos durante la molienda, así como el que se agregó a la mezcla con compuesto de Klein, era yeso puro obtenido por el método de desulfuración de gas. Se molieron todos los componentes hasta obtener una superficie específica de $340 \mathrm{~m}^{2} / \mathrm{kg}$, a excepción el yeso, que se molió hasta una superficie específica de $500 \mathrm{~m}^{2} / \mathrm{kg}$.

Con estos componentes se prepararon cuatro cementos y cuatro pastas, cuya composición se presenta en la Tabla 2.
In addition to these two clinkers, Klein compound was prepared by burning a raw mix with a suitable composition in a small rotary kiln at $1300{ }^{\circ} \mathrm{C}$. X-ray diffraction detected no other components in this material, whose chemically determined free lime content was $0.3 \%$.

Pure gypsum, obtained by gas desulfurisation, was added to the two cements during grinding as well as to the Klein compound blend. With the exception of the gypsum, which was ground to a Blaine fineness of 500 $\mathrm{m}^{2} / \mathrm{kg}$, all components were ground to $340 \mathrm{~m}^{2} / \mathrm{kg}$.

Four cements and four pastes were prepared from these components, as described in Table 2.

Tabla 2 / Table 2

Composición de los cementos y las pastas.

Cement and paste composition.

\begin{tabular}{|c|c|c|}
\hline Pasta / Paste & Contenido por / Content in 100 g & Agua / Water \\
\hline Z1 & $100 \mathrm{~g}$ cemento / cement $1+0.1 \mathrm{~g} \mathrm{25} \mathrm{MP*}$ & $30 \mathrm{~g}$ \\
\hline Z2 & $97 \mathrm{~g}$ cemento / cement $1+3 \mathrm{~g}$ yeso / gypsum $+0.1 \mathrm{~g} \mathrm{25} \mathrm{MP}$ & $30 \mathrm{~g}$ \\
\hline Z3 & $94.85 \mathrm{~g}$ cemento / cement $1+2.65 \mathrm{~g}$ yeso / gypsum $+2.5 \mathrm{~g}$ compuesto de Klein / Klein compound $+0.1 \mathrm{~g} 25 \mathrm{MP}$ & $30 \mathrm{~g}$ \\
\hline Z4 & $97 \mathrm{~g}$ cemento / cement $2+3 \mathrm{~g}$ yeso/gypsum $+0.1 \mathrm{~g} 25 \mathrm{MP}$ & $30 \mathrm{~g}$ \\
\hline
\end{tabular}

Nota / Note: * Nombre comercial del superplastificante. / * Superplasticiser trade name.

Como puede observarse en la Tabla 2 , se empleó la misma relación a/c en todas las pastas: 0,30. El superplastificante utilizado fue un copolímero acrílico formado por tres tipos de grupos derivados de ácido: carboxílico, alquilestérico y poliéster (14).

Las propiedades reológicas de dichas pastas se analizaron con un viscosímetro de rotación Visco 1. La composición por fases de las pastas se determinó mediante DRX, ajustando los resultados obtenidos por el método de Rietveld (15). Por último, el seguimiento del proceso de hidratación se realizó mediante microcalorimetría, con microcalorímetro isotérmico.

\section{RESULTADOS EXPERIMENTALES}

Las curvas de flujo obtenidas se presentan en las Figuras 1-4. Basándose en estos resultados, se calcularon la viscosidad plástica y el esfuerzo umbral de cizalla de todas las pastas mediante el modelo de Bingham. Los valores observados se presentan en la Figura 5.

El valor mínimo del esfuerzo umbral de cizalla se observa en la pasta Z1 preparada con el cemento 1 (sin
As Table 2 shows, the same $w / c$ ratio (0.30) was used throughout. The superplasticizer was an acrylic copolymer comprising three types of acid derivatives: carboxyl, alkyl ester and polyester (14).

The rheological properties of these pastes were examined using a rotoVisco 1 viscometer. Their phase composition was determined by Rietveld refinement of XRD patterns (15). Finally, hydration was monitored by microcalorimetry with an isothermal microcalorimeter.

\section{EXPERIMENTAL RESULTS}

The flow curves obtained are shown in Figures 1 to 4 . On the basis of these findings, the plastic viscosity and yield values for all the pastes were calculated applying the Bingham model. The results are presented in Figure 5.

The 10-minute yield value was lowest in paste $Z 1$, prepared from gypsum-free cement 1 , where it remained 
yeso). En esta pasta (Z1) el valor umbral se mantiene prácticamente constante durante los 120 minutos de duración de la prueba. Le sigue la pasta Z2 (cemento 1 y yeso), cuyo valor umbral de cizalla a los 10 minutos es ligeramente superior, aumentándose de manera significativa entre los minutos 10 y 20 y manteniendo esta tendencia alcista hasta los 120 minutos. El valor umbral de cizalla inicial de la pasta Z3 (cemento 1 y compuesto de Klein) es mucho mayor. Sin embargo, entre los minutos 30 y 60 dicho valor disminuye y sigue disminuyendo hasta el minuto 90, para volver a aumentar entre los minutos 90 y 120 . El mayor valor umbral de cizalla se observa en la pasta Z4, en la que aumenta de forma acusada hasta el minuto 120 .

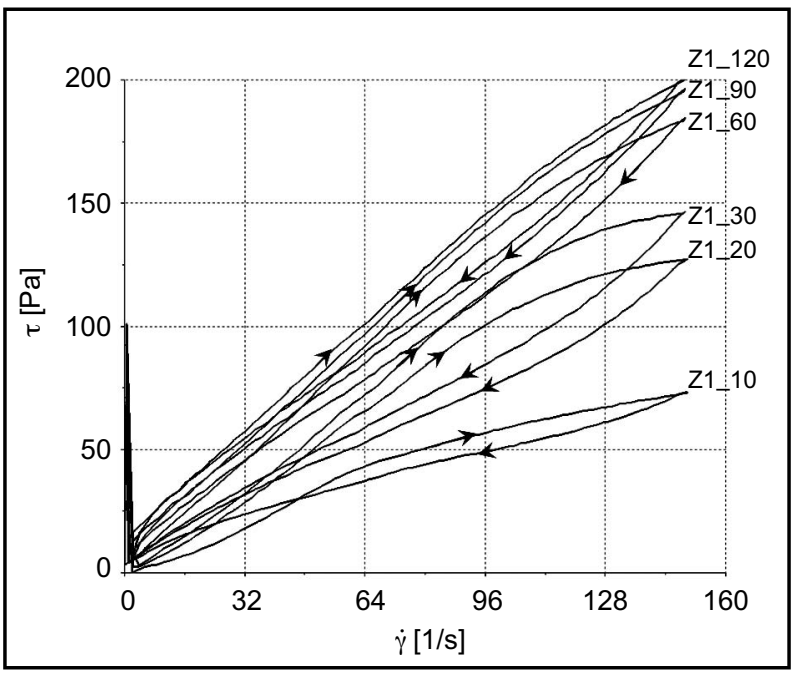

Figura 1. Curvas de flujo de la pasta Z1 (cemento 1). Figure 1. Flow curves for paste Z1 (cement 1).

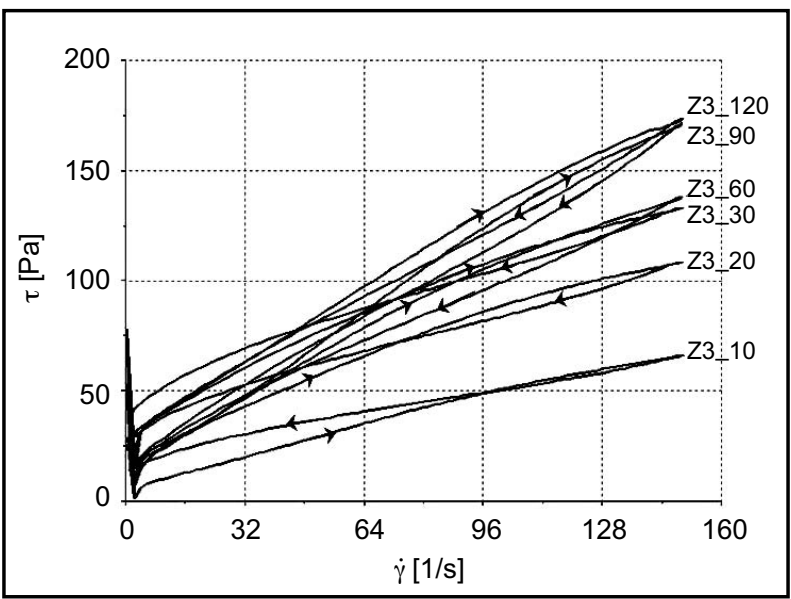

Figura 3. Curvas de flujo de la pasta Z3 (cemento 1, yeso y compuesto de Klein).

Figure 3. Flow curves for paste Z3 (cement $1+$ gypsum + Klein compound).

Si se comparan los valores de viscosidad plástica a los 10 minutos de las cuatro pastas, se observa que éstas se practically constant throughout the 120-minute trial. Paste $Z 2$ (cement $1+$ gypsum) had the second lowest 10-minute value, which rose steeply throughout the test. A much higher initial yield value was obtained for paste Z3, a blend of cement 1 and Klein compound. This value declined sharply between 30 and 60 minutes and continued downward for the next 30 minutes, but rose again thereafter. The highest 10-minute yield value was observed in paste $\mathbf{Z 4}$, in which it continued to rise sharply through the end of the trial.

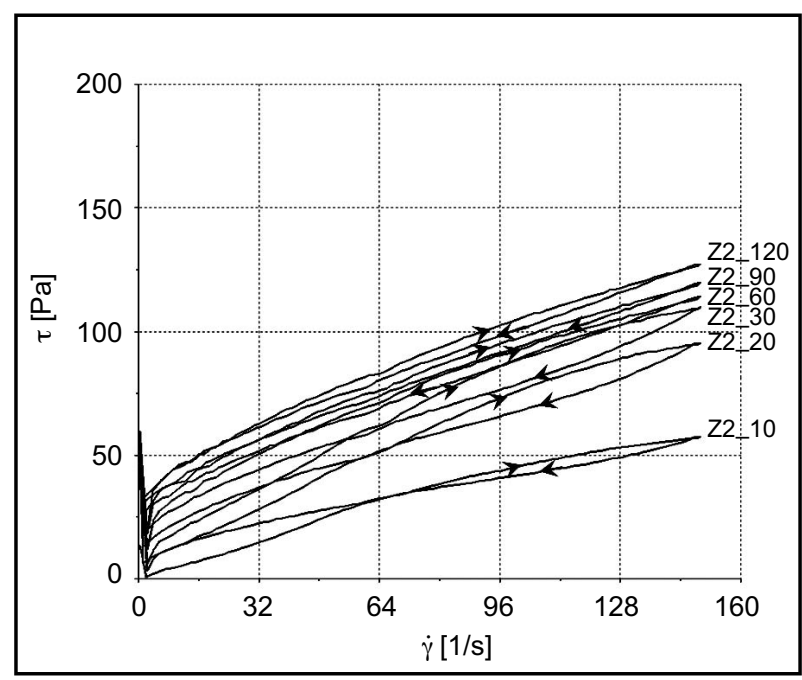

Figura 2. Curvas de flujo de la pasta Z2 (cemento 1 y yeso). Figure 2. Flow curves for paste Z2 (cement $1+$ gypsum).

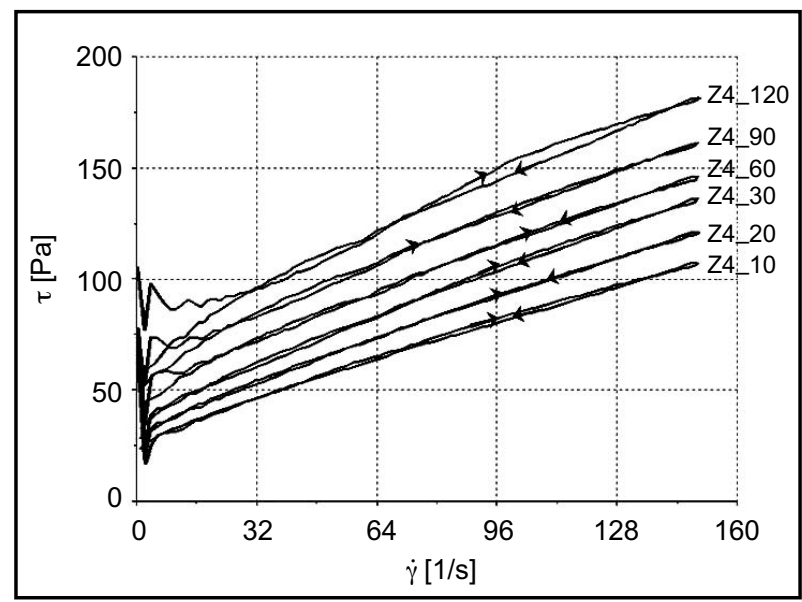

Figura 4. Curvas de flujo de la pasta Z4 (cemento 2 y yeso). Figure 4. Flow curves for paste $Z 4$ (cement $2+$ gypsum).

The four pastes can be ranked by increasing order of 10 minute plastic viscosity as follows: $Z 2=Z 3<Z 1,<Z 4$ 
pueden ordenar de menos viscosas a más del siguiente modo: $\mathrm{Z2}=\mathrm{Z3}<\mathrm{Z1}<\mathrm{Z4}$ (Figura 5). Sin embargo, a los 60 minutos la situación es completamente diferente: Z2 y Z4 tienen una baja viscosidad plástica, mientras que Z3 tiene una elevada viscosidad y $Z 1$, una aún mayor. A los 90 minutos, las mayores viscosidades plásticas corresponden a las pastas Z1 y Z3, mientras que en las pastas Z2 y Z4 su valor aumenta muy poco a lo largo del tiempo. En la pasta Z2 se mantiene prácticamente igual entre los minutos 30 y 90, y apenas aumenta a los 120 minutos.
(Figure 5). That order changed drastically after 60 minutes, however: Z2 and Z4 exhibited low plastic viscosity, which was somewhat higher in Z3 and much higher in Z1. After 90 minutes, the highest plastic viscosity values were observed for pastes $Z 1$ and $Z 3$, while paste $Z 2$ and $Z 4$ viscosity grew only scantly. In paste $Z 2$, plastic viscosity remained practically flat from 30 to 90 minutes, and increased only slightly between 90 and 120 minutes.

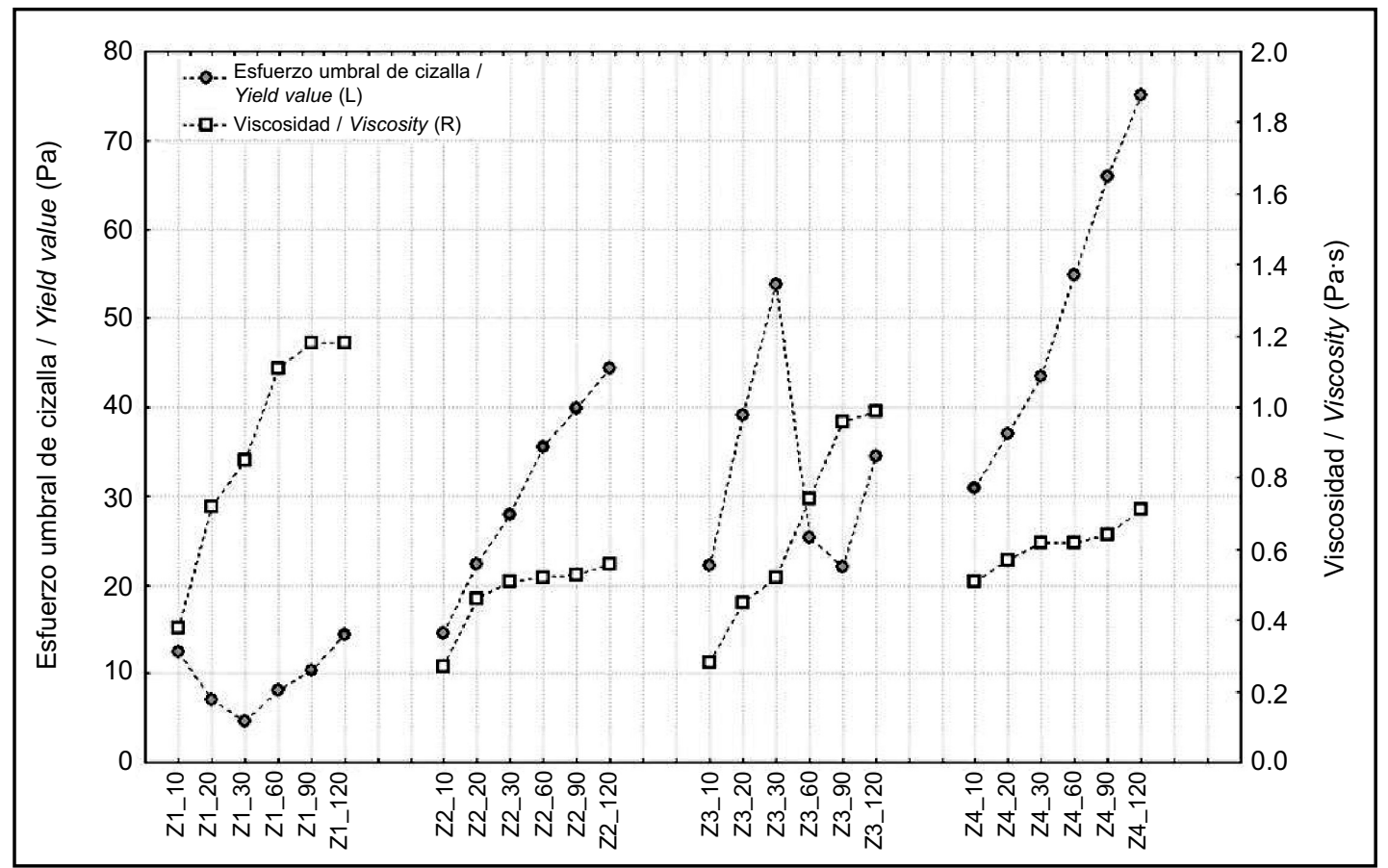

Figura 5. Valor del esfuerzo umbral de cizalla y de viscosidad plástica de las pastas Z1 (cemento 1), Z2 (cemento 1 y yeso), $Z 3$ (cemento 1 , yeso y compuesto de Klein) y Z4 (cemento 2 y yeso).

Figure 5. Yield value and plastic viscosity in pastes Z1 (cement 1), Z2 (cement $1+$ gypsum), Z3 (cement $1+$ gypsum + Klein compound), $Z 4$ (cement $2+$ gypsum).

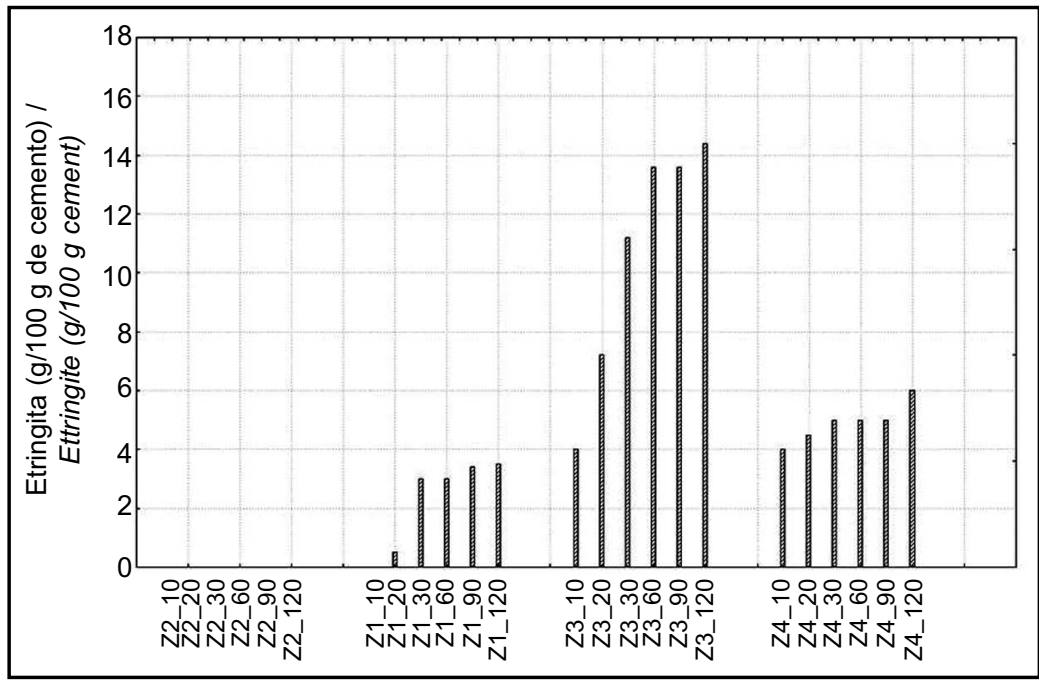

Figura 6. Contenido en etringita de las pastas Z1 (cemento 1), Z2 (cemento 1 y yeso), Z3 (cemento 1 , yeso y compuesto de Klein) y Z4 (cemento 2 y yeso).

Figure 6. Ettringite content in pastes $Z 1$ (cement 1), Z2 (cement $1+$ gypsum), Z3 (cement $1+$ gypsum + Klein compound), Z4 (cement 2 + gypsum). 
En la Figura 6 se presentan los resultados del análisis por DRX de la etringita, en el que se ha empleado el método tradicional, es decir, con patrón interno. Los resultados indican que la pasta $\mathrm{Z} 1$ no contiene etringita y en la Z2 el contenido de esta fase es escaso, mientras que en la Z4 es ligeramente mayor. En estas dos últimas pastas, el contenido en etringita aumenta rápidamente en los primeros diez minutos y luego se mantiene prácticamente constante. El contenido en etringita de la pasta Z3 (a la que se había añadido el compuesto de Klein) aumenta hasta el minuto 60, presentando el valor máximo observado.
The XRD findings on ettringite content, using the classic internal standard method, are shown in Figure 6. The results revealed that $Z 1$ contained no ettringite, $Z 2$ only a small amount of this phase, and Z4 slightly more. In the last two pastes, ettringite content increased rapidly in the first ten minutes and then remained practically constant. The ettringite content was highest in Klein compound-bearing paste $Z 3$ and increased steadily during the first 60 minutes.

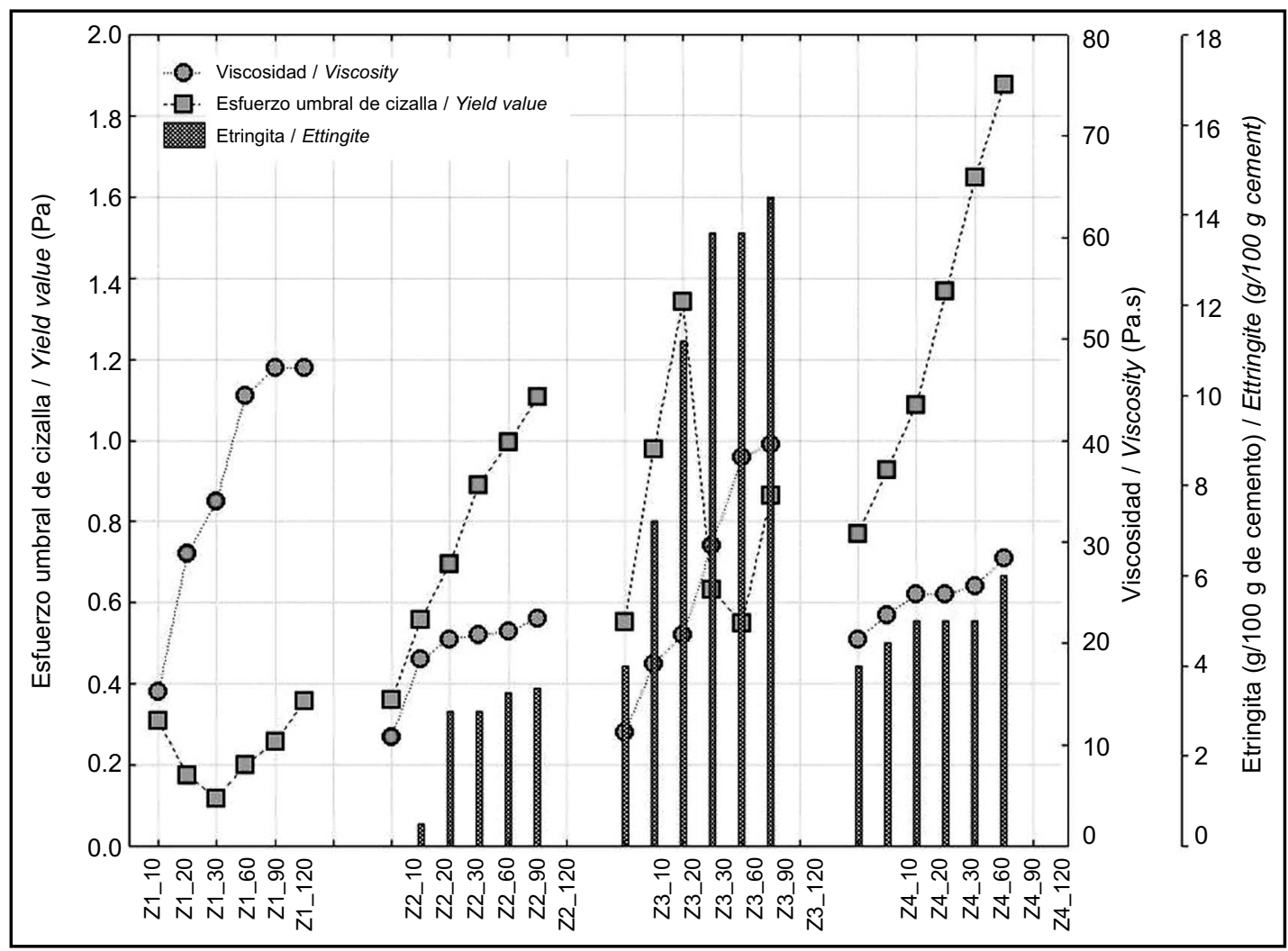

Figura 7. Contenido de etringita, viscosidad plástica y valor umbral de cizalla de las pastas Z1 (cemento 1), Z2 (cemento 1 y yeso), Z3 (cemento 1 , yeso y compuesto de Klein) y Z4 (cemento 2 y yeso).

Figure 7. Ettringite content, plastic viscosity, and yield value: Z1 (cement 1), Z2 (cement $1+$ gypsum), Z3 (cement $1+$ gypsum + Klein compound), $Z 4$ (cement $2+$ gypsum).

Al comparar el contenido en etringita de todas las pastas con las dos propiedades reológicas estudiadas (Figura 7), se ve que existe una correlación entre dicho parámetro y el esfuerzo umbral de cizalla: cuanto mayor sea el contenido en etringita, mayor es el valor umbral de cizalla. Sin embargo, no existe una correlación tan clara entre el contenido en etringita y la viscosidad plástica (Figura 7). La mayor viscosidad se obtiene en el caso de $\mathrm{Z} 1$, que no contiene etringita. No obstante, la viscosidad de las otras tres pastas guarda una cierta relación con el contenido en etringita: cuanto mayor es el contenido en este hidrato, mayor es la viscosidad. En consecuencia,
Ettringite content is compared to the rheological properties in all four pastes in Figure 7 , which shows that it is correlated to yield value: the higher the ettringite content, the greater the yield value. No such simple correlation was found between ettringite content and plastic viscosity, however (Figure 7). Viscosity was greatest in Z1, which contained no ettringite. Nonetheless, in the three remaining pastes viscosity proved to be related to ettringite content: the greater the content of this hydrate, the higher was paste viscosity. For reasons that remain unclear, therefore, the plastic viscosity observed in paste $Z 1$ was an 
por razones que quedan por esclarecer, la viscosidad plástica de la pasta Z1 constituye una excepción, en la que el aumento observado probablemente sea atribuible a la formación del gel CSH.

Los resultados microcalorimétricos demuestran que las pastas presentan valores de calor de hidratación muy similares, tanto a la 1 como a las 2 horas, menos en la pasta Z4, que, tras 1 hora, presenta un valor muy inferior a las demás. A las 41 horas, en cambio, a esta pasta le corresponde el mayor calor de hidratación, seguida de Z3, Z2 y, por último, Z1, que presenta un valor muy inferior al de las otras tres pastas (Tabla 3 y Figura 8). exception to this rule, although the increase was very likely a consequence of $\mathrm{C}-\mathrm{S}$-H gel formation.

The microcalorimetric measurements taken showed that heat of hydration was very similar in all the pastes after 1 and 2 hours, with the sole exception of $Z 4$ which, after 1 hour, exhibited a much lower value. After 41 hours, heat of hydration in the pastes was, in decreasing order: Z4 > Z3 > Z2 > Z1. This parameter was substantially lower in $Z 1$ than in the other three pastes, however (Table 3 and Figure 8).

Tabla 3 / Table 3

Calor de hidratación $(\mathrm{J} / \mathrm{g})$.

Heat of hydration, $\mathrm{J} / \mathrm{g}$.

\begin{tabular}{|c|c|c|c|c|}
\hline \multirow{2}{*}{$\begin{array}{c}\text { Tiempo de hidratación / } \\
\text { Hydration time (h) }\end{array}$} & $\mathbf{Z 1}$ (cemento / cement 1) & $\begin{array}{c}\mathrm{Z2} \text { (cemento / cement 1 y } \\
\text { yeso / + gypsum) }\end{array}$ & $\begin{array}{c}\mathrm{Z3} \text { (cemento / cement 1, } \\
\text { yeso y compuesto de } \\
\text { Klein / + gypsum + Klein } \\
\text { compound) }\end{array}$ & $\begin{array}{c}\text { Z4 (cemento / cement 2 y } \\
\text { yeso /+ gypsum) }\end{array}$ \\
\hline 1 & 0.53 & 0.55 & 0.40 & 0.33 \\
\hline 2 & 0.62 & 0.74 & 0.64 & 0.65 \\
\hline 41 & 27.1 & 81.9 & 82.1 & 113.6 \\
\hline
\end{tabular}

En todas las pastas se incorporó un $0,1 \%$ de superplastificante. / All pastes contained $0.1 \%$ superplasticizer.

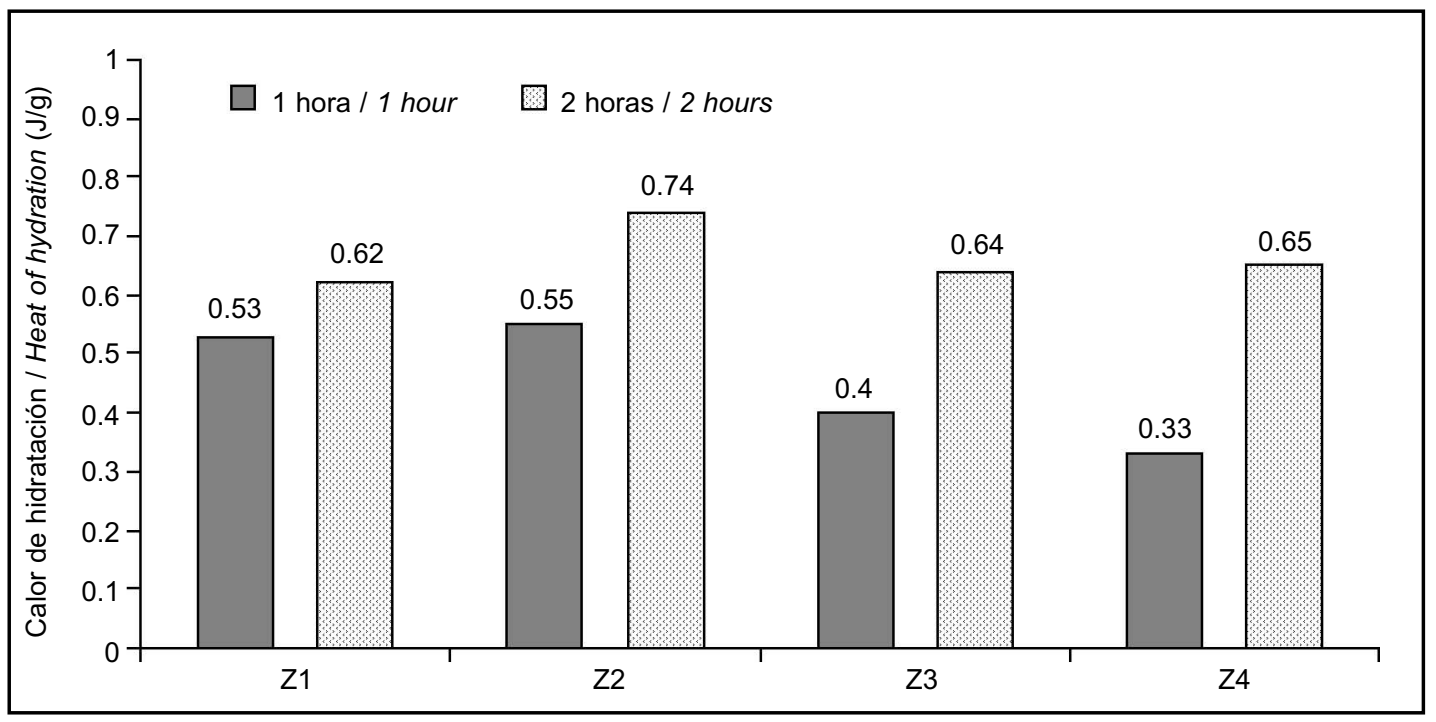

Figura 8. Calor de hidratación de las pastas.

Figure 8 . Heat of hydration of pastes.

Las diferencias observadas entre los valores de calor de hidratación de las pastas en las primeras dos horas son demasiado insignificantes como para proporcionar información que pueda justificar su comportamiento reológico. El resultado más relevante en este sentido es la inexistencia de relación entre el calor de hidratación y la cantidad de etringita que se forma. La única conclusión
The minor differences between the heat of hydration values in the pastes for the first 2 hours provided little information that might explain their rheological behaviour. The most meaningful finding was that heat of hydration was not proportional to the quantity of ettringite formed. The only conclusion that could be drawn from this analysis, especially after 41 hours, was 
a la que puede llegarse al evaluar el calor de hidratación, en especial a las 41 horas, es que el cemento Z4, que contiene $C_{3} A$, es mucho más reactivo que el cemento $Z 1$, que tiene un elevado contenido en $\mathrm{C}_{4} \mathrm{AF}$.

\section{CONCLUSIONES}

Los resultados obtenidos en el presente trabajo demuestran que no es el contenido de $\mathrm{C}_{3} \mathrm{~A}$, sino el de la etringita que se forma, lo que afecta de manera decisiva al comportamiento reológico de las pastas de cemento que llevan incorporados superplastificantes basados en carboxilatos. Existe una buena correlación entre este parámetro y el esfuerzo umbral de cizalla, pero no tanto entre la formación de etringita y la viscosidad plástica. Esta última propiedad presenta valores contrarios al valor umbral de cizalla: cuanto mayor es éste, menor es la viscosidad plástica. Sin embargo, en los dos sistemas parecidos (Z2, con cemento 1 y yeso, y Z4, con cemento 2 y yeso), la correlación entre los parámetros reológicos y el contenido de etringita es buena. La única excepción es la pasta $\mathrm{Z1}$, que no contiene etringita y presenta una elevada viscosidad plástica. La relación indirecta entre el valor umbral de cizalla y la viscosidad plástica no puede explicarse a partir del presente estudio, por lo que serán necesarias investigaciones posteriores.

Cabe destacar que la etringita puede formarse rápidamente a partir de $\mathrm{C}_{4} \mathrm{AF}$, como queda patente en la pasta $\mathrm{Z2}$.

Asunto aparte es el de las vicisitudes observadas en el valor umbral de cizalla de la pasta que contenía compuesto de Klein. El rápido aumento y posterior caída de este parámetro reológico no pueden explicarse a partir del trabajo experimental realizado con motivo de esta investigación. Sin embargo, puede proponerse una explicación basada en los análisis de pastas de cemento con compuesto de Klein llevados a cabo con técnicas de MEB hace algunos años, según los cuales, en este tipo de sistemas la etringita se forma principalmente en el espacio que anteriormente ocupaba el agua. Por otra parte, en dichos sistemas la mayoría de los cristales no está unida a partículas de cemento, lo que permite que se reorienten en paralelo al flujo de la pasta durante las pruebas reológicas. Esto podría explicar el extraño comportamiento de la pasta Z3. that paste $Z 4$, which contained $C_{3} A$, was much more reactive than paste $Z 1$, which had a high $C_{4} A F$ content.

\section{CONCLUSIONS}

The experimental findings in this study showed that the amount of ettringite formed, rather than the $C_{3} A$ content, was the determining factor in the rheological behaviour of cement pastes in the presence of a carboxylate superplasticiser. The correlation was fairly high for yield value, but less clear for plastic viscosity, which was indirectly related to the yield value: the higher the yield value, the lower the plastic viscosity. In the two similar systems, such as Z2 (cement $1+$ gypsum) and Z4 (cement $2+$ gypsum), however, a high correlation was observed between the rheological parameters and ettringite content. The sole exception was paste Z1, which contained no ettringite but exhibited high plastic viscosity. The indirect relationship between yield value and plastic viscosity cannot be explained on the basis of experimental results and requires further study.

Ettringite can form quickly from $C_{4} A F$, as in paste $Z 2$.

The unusual changes in yield values in the paste containing Klein compound merits comment. The steep rise followed by a decline in this rheological parameter cannot be explained on the basis of the experimental research conducted here. A plausible explanation may be put forward, however, based on SEM observations of Klein compound-containing cement paste made some years ago. In such systems, ettringite forms primarily in the space previously occupied by water and most of the crystals are not linked to the cement particles. Consequently, rearrangement parallel to the paste flow would be possible during rheological trials, which would account for the unusual behaviour of paste $Z 3$.

\section{BIBLIOGRAFÍA / BIBLIOGRAPHY}

(1) Erdogdu, S.: "Compatibility of superplasticizers with cements different in composition". Cem. Conc. Res., vol. 30, no 5 (2000), pp. 767-773. doi:10.1016/S0008-8846(00)00229-5

(2) Jiang, S.; Kim, B.-G.; Aïtcin, P.-C.: "Importance of adequate soluble alkali content to ensure cement/superplasticizer compatibility", Cem. Conc. Res., vol. 29, no. 1 (1999), pp. 71-78. doi:10.1016/S0008-8846(98)00179-3

(3) Aïtcin, P.-C.: "Domieszki: najważniejszy skladnik nowoczesnego betonu", Cement Wapno Beton, vol. 11/73, nº 5 (2006), pp. $277-284$. 
(4) Ramachandran, V. S.; Malhotra, V. M.; Jolicoeur, C. and Spiratos, N.: Superplasticizers, Properties and applications in Concrete, Minister of Public works and government Services, Canada, 1998.

(5) Golaszewski, J.: "Reologia zapraw a reologia mieszanek betonowych", Cement Wapno Beton, vol. 11/73, no 1 (2006), pp. 17-28. (6) Bonen, D.; and Sarkar, S. L.: "The superplasticizer adsorption capacity of cement pastes, pore solution composition, and parameters affecting flow loss", Cem. Conc. Res., vol. 25, no 7 (1995), pp. 1423-1434. doi:10.1016/0008-8846(95)00137-2

(7) Nawa, T. and Eguchi, H.: "Effect of cement characteristics on the fluidity of cement paste containing an organic admixture", 9th ICCC, vol. IV, New Delhi (1992), pp. 597-603.

(8) Prince, W.; Espagne, M.; Aïtcin, P.C.: "Ettringite formation: A crucial step in cement superplasticizer compatibility", Cem. Conc. Res., vol. 33, no 5, (2003), pp. 635-641. doi:10.1016/S0008-8846(02)01042-6

(9) Tagnit-Hamou, A.; Baalbaki, M.; Aïtcin, P. C.: "Calcium sulphate optimization in low water/cement ratio concretes for rheological purposes", 9th ICCC, vol. V (1992), pp. 21-25.

(10) Kim, B.G.; Jiang, S., Jolicoeur, C.; Aïtcin, P.C.: "The adsorption behavior of PNS superplasticizer and its relation to fluidity of cement paste", Cem. Conc. Res., vol. 30, no 6 (2000), pp. 887-893. doi:10.1016/S0008-8846(00)00256-8

(11) Prince, W.; Edwards-Lajnef, M.; Aitcin, P.C. : "Interaction between ettringite and a polynaphthalene sulfonate superplasticizer in a cementitious paste", Cem. Conc. Res., vol. 32, no 1 (2002), pp. 79-85. doi:10.1016/S0008-8846(01)00632-9

(12) Massaza, F., and Costa, U.: "Effect of superplasticizers on the $C_{3} A$ hydration", 7th ICCC, vol. IV, Paris (1980), pp. 529-534.

(13) Andersen, P. J.; Kumar, A.; Roy, D. M.; Wolfe-Confer, D.: "The effect of calcium sulphate concentration on the adsorption of a superplasticizer on a cement: Methods, zeta potential and adsorption studies", Cem. Conc. Res., vol. 16, no 2 (1986), pp. 255-259. doi:10.1016/0008-8846(86)90142-0

(14) Grzeszczyk, S. and Sudol, M.: "Wplyw struktury superplastyfikatorów akrylowych na wlasności reologiczne zaczynów cementowych", Cement Wapno Beton, vol. 8/70, no 3, (2003), pp. 156-160.

(15) Ángeles, G.; de la Torre and Aranda, M. A. G.: "Rietveld mineralogical analysis of Portland cement", 11th ICCC, vol. 1, Durban (2003), pp. 135-145. 